\title{
INVESTING IN DEVELOPMENT: THE ROLE OF DEMOCRACY AND ACCOUNTABILITY IN INTERNATIONAL INVESTMENT LAW
}

\author{
GRAHAM MAYEDA*
}

This article explores whether international investment agreements (IIAs) have the potential to impede democratic expression and, as a result, hinder sustainable development. The author first demonstrates that democracy plays an essential role in the promotion of sustainable development and provides a normative (rather than procedural) definition of democracy. The three ways in which IIAs can limit democracy are then addressed. First, they can limit the policy space of developing countries. This is demonstrated through an analysis of how types of provisions commonly found in IIAs can negatively affect policy flexibility. Second, democracy can be indirectly limited through the decisions of international investment tribunals which give little deference to the decisions of domestic democratic forums. Third, democracy can be undermined if foreign investors are not accountable to any democratic government. In this regard, it is necessary for IIAs to impose obligations on home states and investors to ensure that investors behave in socially responsible ways. The article concludes with suggestions for ways in which developing countries can structure IIAs to support democracy rather than detract from it.
Cet article vise à établir si les ententes internationales de placement peuvent potentiellement entraver l'expression démocratique et par conséquent nuire au développement durable. L'auteur démontre dans un premier temps que la démocratie joue un rôle essentiel dans la promotion du développement durable et qu'elle fournit une définition normative (au lieu de procédurale) de démocratie. Les trois manières dont les ententes internationales de placement peuvent restreindre la démocratie y sont ensuite abordées. Premièrement, elles peuvent limiter l'espace politique des pays en voie de développement, tel que démontré par l'analyse de la manière dont les types de provisions, que l'on trouve dans ces ententes, peuvent influer négativement sur la souplesse politique. Deuxièmement, la démocratie peut être indirectement limitée par les décisions des tribunaux internationaux de placement qui n'ont que peu d'égards pour les décisions des tribunes démocratiques intérieures. Troisièmement, la démocratie peut être minée si les investisseurs étrangers ne doivent pas rendre de comptes à un gouvernement démocratique. À cet égard, il est nécessaire que ces ententes imposent des obligations aux États et investisseurs d'origine afin de veiller à ce que les investisseurs se comportent de manière socialement responsable. L'article se termine avec des suggestions de moyens pour les pays en voie de développement de structurer ces ententes afin d'appuyer ces ententes ou lieu de s'en écarter.

\section{TABLE OF CONTENTS}

I. Setting the Scene — The VIVENDi Decision . . . . . . . . . . . . . . 1010

II. INTRODUCTION: DEMOCRACY AND INVESTMENT . . . . . . . . . . . . 1011

III. THE IMPORTANT ROLE OF DEMOCRACY IN

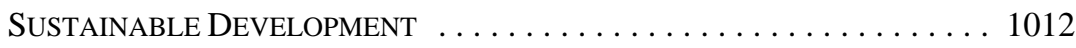

IV. What Is Democracy? ........................... 1015

V. INTERNATIONAL INVESTMENT AGREEMENTS CAN LIMIT

the Policy SPace of Home States . . . . . . . . . . . . . . . . . . . . 1018

A. EXPROPRIATION . . . . . . . . . . . . . . . . . . . . . . . . . . 1020

B. Fair and Equitable TREatment $\ldots \ldots \ldots \ldots \ldots \ldots \ldots \ldots$

Associate Professor, Faculty of Law, University of Ottawa. I would like to thank Joanna Harrington and Craig Forcese for organizing the Four Societies Second Workshop on International Law and Democratic Theory, held at the University of Alberta. The workshop provided a stimulating and inspiring environment. I gratefully acknowledge the support of the Canadian Council on International Law, whose funding permitted me to attend the workshop which gave rise to this article. 
VI. INTERNATIONAL INVESTMENT TRIBUNALS CAN UNDERMINE

DEMOCRACY BY IGNORING THE NORMS AND VALUES OF

DOMESTIC DEMOCRATIC FORUMS . . . . . . . . . . . . . . . . . . . . . . 1028

A. SeCond-Guessing the Public Interest . . . . . . . . . . . . . . . . . 1029

B. INTERPRETATION OF NATIONAL LAW

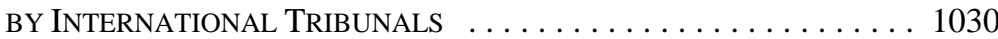

C. EXHAUSTION OF DOMESTIC REMEDIES . . . . . . . . . . . . . . . . . 1033

VII. Promoting Democracy by Imposing Duties on Home States

AND INVESTORS TO KEEP INVESTORS ACCOUNTABLE . . . . . . . . . . . 1033

VIII. SUMMARY: LESSONS TO BE LEARNED FROM

INTERNATIONAL INVESTMENT AGREEMENTS . . . . . . . . . . . . . . 1034

IX. CONCLUding REMARKS: Is PROVIDING GREATER FREEDOM

TO DOMESTIC GOVERNMENTS AT THE EXPENSE OF FOREIGN

INVESTORS REALLY DEMOCRACY? . . . . . . . . . . . . . 1036

X. THE END OF THE STORY - VIVENDI

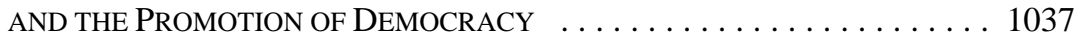

\section{SETTING THE SCENE - THE VIVENDI ${ }^{1}$ DECISION}

In 1995, the government of Carlos Menem (1989-1999) undertook sweeping privatization in Argentina. One of the beneficiaries of this privatization was an Argentine company, Compañía de Aguas del Aconquija (CAA), an affiliate of a French company whose successor company is Vivendi Universal. CAA provided water to the Province of Tucumán under a concession agreement with the province. As a result of CAA's takeover of the water utility, residents of Tucumán saw the cost of water jump on average by 110 percent. $^{2}$ As well, while CAA was providing its services, two instances of water turbidity occurred that turned the water red in one case and black in another. Although experts did not feel that the turbidity posed a risk to residents' health, the utility was accused of not providing drinkable water. Tucumán officials issued a resolution that declared CAA to have been at fault for the episodes of water turbidity. They also told the public that the concession agreement was illegal and advised customers not to pay their bills. ${ }^{3}$

Although CAA and Tucumán authorities renegotiated the concession agreement to reduce the cost of water, the agreement was rejected by the Tucumán legislature. When CAA initiated proceedings at the International Centre for Settlement of Investment Disputes (ICSID), alleging that Argentina had violated the terms of the Argentina-France Bilateral Investment Treaty (BIT), a final attempt at renegotiation was made. However, without CAA's knowledge, 70 changes had been made to the new agreement before it came for approval by the legislature. CAA finally terminated the concession agreement, but it was forced to continue to provide water for almost a year after termination. As well, because the ombudsman and various elected officials had advised customers that they were not obliged to pay their bills, CAA was not able to recover all of the amounts owing to it. In order to 
thwart court orders to the contrary, the Tucumán legislature passed legislation to prevent CAA from collecting the damages owed to the company pursuant to the court judgments. ${ }^{4}$ Finally, tax authorities demanded that CAA pay income tax on the invoices for which CAA had not obtained payment. As a result, a court order was obtained attaching CAA's assets in Tucumán. ${ }^{5}$

Is this an example of democracy in action? Were Argentines, through their elected officials, simply expressing their dissatisfaction with a doubling of the cost of water - an essential service - that resulted from the privatization of the water utility carried out by Menem? Does the ICSID decision finding against Argentina undermine a democratic process, or expose Argentine democracy as a sham? This is the question that this article seeks to resolve, along with the more general question of whether international investment agreements (IIAs), such as that between Argentina and France, have the potential to impede democratic expression, an important element of sustainable development.

\section{INTRODUCTION: DEMOCRACY AND INVESTMENT}

There are three principal ways in which IIAs can undermine democracy. First, an IIA can narrow the policy space for the government of a host state. For instance, if an IIA contains a broad definition of expropriation and requires compensation for all government acts that fall within that definition, then there will be less room for a government to enact laws or regulations that pursue a public purpose - say the alleviation of poverty - if they result in the diminution of the value of a foreign investor's investment. This is because the requirement to pay compensation may be a disincentive, particularly for a poor country.

Second, an IIA can limit democracy indirectly through the process of dispute resolution. If an IIA permits arbitrators to consider the public purpose and the necessity of a domestic measure that reduces the value of a foreign investor when determining if a breach of the agreement has occurred, it empowers arbitrators to review a government's reasons for implementing the measure. After all, the measure could be a sham implemented for the purpose of harming foreign investors. However, in evaluating the existence of a valid public purpose and the necessity of the measure, the court is also second-guessing a decision that may have been arrived at through democratic means. ${ }^{6}$ This opens the door to a tribunal imposing its own standards of what a proper public purpose or a situation of necessity is, without giving due consideration to the norms and values of the nationals of the host state.

Third, democracy can be undermined if foreign investors are not accountable to any democratic government, be it that of the home or the host state. Generally, the purpose of an IIA is to insulate foreign investors from certain changes to the laws and regulations of the host state that could potentially affect the investment environment. However, insulating international investors can make it difficult for the host state to implement measures to

Law No. 7234, 5 September 2002.

Vivendi, supra note 1 at para. 4.22.3.

See Steven P. Croley \& John H. Jackson, "WTO Dispute Procedures, Standard of Review, and Deference to National Governments” (1996) 90 A.J.I.L. 193. Croley and Jackson discuss this issue in their paper on the appropriate standard of review and the level of deference that World Trade Organization (WTO) tribunals should show to the decisions of national agencies and courts. 
require both foreign and domestic investors to manage their investments in a socially responsible way with due regard for international human rights, labour rights, the rights of indigenous peoples, environmental obligations, and so on.

In this article, I will examine all three of the ways in which IIAs can limit democracy. I will address the first concern about narrowing the policy space of developing countries by considering three types of provisions commonly found in IIAs: the prohibition on expropriation, the requirement of fair and equitable treatment, and the exhaustion of domestic remedies. These will be evaluated in order to demonstrate how they can negatively affect policy flexibility. The second concern about the lack of democratic legitimacy of international investment tribunals will be addressed by examining how these tribunals give little deference to the domestic tribunals of the host state. The lack of deference has the potential to supplant the decision of a domestic tribunal that forms part of the process of democratic will-formation with one that is not plugged into this process. Finally, I will address the third concern by briefly commenting on the necessity for IIAs to impose obligations on home states and investors to ensure that investors behave in socially responsible ways. Before turning to these three issues, in the next two sections, I examine the role of democracy in the promotion of sustainable development and provide a normative (rather than procedural) definition of democracy.

\section{THE IMPORTANT ROLE OF DEMOCRACY IN SUSTAINABLE DEVELOPMENT}

Are IIAs inherently undemocratic, or is it possible to have an investment regime that is compatible with democracy? This question is part of a wider debate about the inherent dangers that market economies pose to democracy. ${ }^{7}$ This danger was identified by Adam Smith, who pointed out in 1776 that democracy pits the masses against the propertied minority: "For one very rich man, there must be at least five hundred poor.... The affluence of the rich excites the indignation of the poor, who are often both driven by want, and prompted by envy, to invade his possessions." ${ }^{8}$ Robert A. Dahl identifies the tension to which Smith points as arising from concerns about property rights: either the majority can use its democratic voice to threaten the property rights of the propertied minority, or else property rights might be used as a base of power that permits the minority of property owners to dominate the majority, thus undermining democracy. ${ }^{9}$

Given the potential for conflict between democracy and the protection of the property owned by foreign investors, can democracy and international investment ever complement rather than detract from each other? Amy L. Chua suggests that democracy and development

$7 \quad$ Karl Marx, The Class Struggles in France: 1848-1850, trans. by Henry Kuhn (Brooklyn: New York Labor News, 1924) at 89; Robert A. Dahl, A Preface to Economic Democracy (Berkeley: University of California Press, 1985) at 62-73. For the opposite view that democracy and markets reinforce each other, see Jagdish Bhagwati, “The New Thinking on Development” (1995) 6:4 Journal of Democracy 50; Lester C. Thurow, The Future of Capitalism: How Today's Economic Forces Shape Tomorrow's World (New York: W. Morrow, 1996) at 1-5; Roberto Mangabeira Unger, Democracy Realized: The Progressive Alternative (London: Verso, 1998) at 3-4. 
will work together if a bargain is struck between the poor majority and the rich minority. The bargain is that increased investment will increase overall prosperity, and that the increased wealth will be redistributed through welfare state mechanisms. This bargain is further reinforced by “market-compatible ideologies” that ensure that the poor are lulled into a belief system that discourages them from rebelling against the disparities in income that are created by the expansion of the market economy and the attraction of international investment. ${ }^{10}$ For instance, the ideology of upward mobility stupefies the masses by making them believe that they too will one day be sharing the wealth of the minority. ${ }^{11}$ Admittedly, Chua's view does not demonstrate an ideological compatibility between democracy and development. However, it does demonstrate that where a "bargain” of the sort Chua describes is struck, democracy and economic development can coexist.

One of the major problems with international investment law is that there is, as yet, no good bargain between the poor and the rich of the kind that Chua identifies because it is unclear whether IIAs increase overall prosperity. ${ }^{12}$ As Bernard Hoekman and Richard Newfarmer point out, "[t]he legal and macroeconomic consequences of broad investment rights are largely unknown. They have not been thoroughly analyzed, tested in arbitration cases, and are without precedent."13 Thus, rather than reinforcing democracy, the IIAs promoted by developed countries may in fact undermine it, since a separate legal regime for foreign investment may place foreign investors outside of the reach of domestic policymakers, which benefits foreign investors without providing consideration to nationals of the host state. This is short-sighted for two reasons. First, democracy and accountability are two important elements of sustainable development, ${ }^{14}$ which is increasingly important in

Amy L. Chua, “The Paradox of Free Market Democracy: Rethinking Development Policy” (2000) 41 Harv. Int'l L.J. 287 at 290.

11 Ibid. at 301-302. Chua mentions other ideologies such as that of self-reliance: the self-reliant person is proud of self-sufficiency achieved through the market, rather than envying the rich (at 303-304); the ideology of the valued employee: ensuring that lower-paid employees have a stake in the success of their employer and the economy as a whole (at 305); the idea of worker control, which ensures that workers have a sense of self-governance and self-determination (at 304-305); and racism, which ensures that the poor of one race will feel superior to the poor of another race, and ensures that no coalition can be built based on socio-economic class due to the race divide (at 305-306).

$12 \quad$ Kevin P. Gallagher \& Lyuba Zarsky, "No Miracle Drug: Foreign Direct Investment and Sustainable Development” in Lyuba Zarsky, ed., International Investment for Sustainable Development: Balancing Rights and Rewards (London: Earthscan, 2005) 13 (in a review of 11 studies of the effects of foreign investment on economic growth, Gallagher and Zarsky found that only two studies had found a positive relationship between investment and growth, one found a negative relationship, and the rest concluded that factors specific to each country accounted for the relationship between investment and growth).

13 Bernard Hoekman \& Richard Newfarmer,"Preferential Trade Agreements, Investment Disciplines and Investment Flows” (2005) 39 J. World Trade 949 at 966.

14 Amartya Sen sees these elements as fundamental aspects of his capabilities approach to development: Amartya Sen, Development as Freedom (New York: Knopf, 1999) at 38-40, 160-68. The promotion of democracy is also a part of the development strategy of many developed country governments. For instance, the Canadian International Development Agency has an Office for Democratic Governance whose mandate is described as follows: "to promote freedom and democracy, human rights, the rule of law and open and accountable public institutions in developing countries": "Office for Democratic Governance” online: Canadian International Development Agency <http://www.acdi-cida.gc.ca/CIDA WEB/acdicida.nsf/En/NIC-54102116-JUN>. The United States Agency for International Development (USAID) has a similar program: online: USAID <http://www.usaid.gov/our_work/democracy_and _governance/>. On the efforts of democratic states to promote democracy, see Roland Rich, "Bringing Democracy into International Law” (2001) 12:3 Journal of Democracy 20. 
international law. ${ }^{15}$ Second, by promoting democracy in their developing country investment partners, developed countries will be able to secure the stability of the investments of their nationals. I will address the second point later in this article. But I now briefly turn to the relationship between democracy and sustainable development.

First, international human rights include a right to democratic government. Article 21 of the Universal Declaration of Human Rights states that " $[\mathrm{t}]$ he will of the people shall be the basis of the authority of government." "Similarly, art. 1 of the International Covenant on Civil and Political Rights asserts that "[a]ll peoples have the right of self-determination. By virtue of that right they freely determine their political status and freely pursue their economic, social and cultural development.”17 In 1999, the United Nations Commission on Human Rights adopted a resolution on the right to democracy, which affirms that democracy is essential for the promotion and achievement of all human rights. ${ }^{18}$ I have already noted that the practice of many developed country democracies is to include democratic capacitybuilding in their development programs. As Thomas M. Franck asserts, these documents and others give evidence of an emerging international entitlement to democracy, although he notes that this entitlement still lacks coherent principles to give it concrete meaning. ${ }^{19}$ But democracy is not just an important human right - it is an essential component of sustainable development, not least because democracy makes it more difficult for the benefits of economic growth to be funnelled into the pockets of individuals. ${ }^{20}$ The question is, how does this obligation and desire to promote democracy affect the use of IIAs?

15 See Declaration on the Right to Development, GA Res. 41/128, UN GAOR, 41st Sess., UN Doc. A/RES/41/128 (1986) 186; Millennium Development Goals, online: United Nations <http://www.un. org/millenniumgoals/>. Some authors have argued that the Millennium Development Goals (MDG) articulate customary international law obligations that states are now obliged to fulfill: see Gobind Nankani, John Page \& Lindsay Judge, "Human Rights and Poverty Reduction Strategies: Moving Towards Convergence?” in Philip Alston \& Mary Robinson, eds., Human Rights and Development: Towards Mutual Reinforcement (Oxford: Oxford University Press, 2005) 475. Others are more circumspect: see e.g. Philip Alston, "Ships Passing in the Night: The Current State of the Human Rights and Development Debate Seen Through the Lens of the Millennium Development Goals” (2005) 27 Hum. Rts. Q. 755 at 774 (the first six MDG, and maybe part of the seventh, are parts of customary international law, but not the eighth goal).

16 Universal Declaration of Human Rights, GA Res. 217(III), UN GAOR, 3d Sess., Supp. No. 13, UN Doc. A/217(111) (1948) 71, art. 21. See also International Covenant on Civil and Political Rights, 19 December 1966, 999 U.N.T.S. 171, art. 25 (entered into force 23 March 1976) [ICCPR]; General Comment No. 25: The right to participate in public affairs, voting rights and the right of equal access to public service (Art. 25), 57th Sess., UN Doc. CCPR/C/21/Rev.1/Add.7 (1996) [General Comment No. 25] (giving meaning to art. 25 of the ICCPR).

17 ICCPR, ibid., art. 1 . Article 25 of the ICCPR provides for a right of political participation. However, this right has been given more development toward a right of democratic government in statements of the Human Rights Committee (General Comment No. 25, ibid.); UN Commission on Human Rights (Promotion of the Right to Democracy, ESC Res. 1999/57, UN ESCOR, 55th Sess., UN Doc. E/CN.4/1999.SR 57 (1999)); the Organization of American States (OAS, General Assembly, 5th Plen. Sess., Representative Democracy, OR OEA/AG/RES. 1080 (XX1-O/91) (1991)); and the UN General Assembly (Enhancing the effectiveness of the principle of periodic and genuine elections, GA Res. 45/150, UN GAOR, 45th Sess., UN Doc. A/RES/45/150 (1990) 254).

18 Promotion of the Right to Democracy, ibid. at para. 1. The exact wording is: "Affirms that democracy fosters the full realization of all human rights, and vice versa."

19 Thomas M. Franck, “The Emerging Right to Democratic Governance” (1992) 86 A.J.I.L. 46.

20 Jack Donnelly, “Human Rights, Democracy, and Development” (1999) 21 Hum. Rts. Q. 608 at 610. 


\section{WHAT IS DEMOCRACY?}

Defining democracy is always a challenge. Democracy can be defined in terms of the existence of certain key institutions. For instance, Franck examines the emerging right to democratic governance in terms of the existence of three institutions: self-determination, participation in elections, and free political expression. ${ }^{21}$ An institutional model also underlies the "transition" model of democracy, a popular model for explaining the process of economic development. The basic model involves three stages: a period of opening, during which the previous authoritarian regime begins to fail, followed by a breakthrough and the introduction of democracy, and ending with a period of gradual consolidation, during which democratic institutions (such as a free press, strong civil society, and regular elections) are strengthened. Progression along the "road to democracy" is marked by the dissolution of old authoritarian institutions and the progressive establishment of democratic ones. The paradigm promises a progressive, though not necessarily smooth, transition to democracy.

In this article, I do not adopt an institutional definition of democracy. There are several reasons for this. First, the presence of particular institutions is not an accurate indicator of the existence of democracy. As Thomas Carothers points out, the transition paradigm is not a faithful description of the democratization process. Rather than a continual progress along the road to democracy, many governments stall before "full" democratization is reached. ${ }^{22}$ Most countries are in a "gray zone,” with clear “democratic deficits” such as:

(1) “[P]oor representation of citizens’ interests,

(2) low levels of political participation beyond voting,

(3) frequent abuse of the law by government officials,

(4) elections of uncertain legitimacy,

(5) low levels of public confidence in state institutions, and

(6) persistently poor performance [of state institutions].”23

Carothers describes states in this gray zone as either suffering from "feckless pluralism" or "dominant-power" elites. ${ }^{24}$ A feckless pluralist state is characterized by: little voter participation in decision-making beyond voting, corrupt politicians, the absence of a political party that can deal effectively with political issues, a disaffected public, the domination of politics by elites, and policies that are poorly conceived and executed. A country with a dominant-power elite has the following problems: it is dominated by one party or leader, the line between the state and the ruling party is blurred, the ruling party has control over the main assets of the state, elections are either fraudulent or of dubious accuracy, and the 
citizens are disaffected with politics and have few opportunities to participate in decisionmaking. ${ }^{25}$ As can be seen from these descriptions, the existence of the institutions of democracy (for example, voting, division of powers, and courts) is not highly correlated with greater decision-making power for citizens.

Second, an institutional model overlooks the normative content of democracy by focusing on the presence of institutions rather than on the normative framework in which those institutions operate. The danger of using such an institutional model is that it ignores the possibility that democracy could be instantiated in a variety of different institutional models. By having a normative concept of democracy rather than an institutional one, it is possible to recognize democratic practices in countries with a variety of different social, cultural, and political practices. ${ }^{26}$

Third, a purely institutional model fails to capture what we mean by promoting “democracy.” As Jack Donnelly points out, human rights are not compatible with a limited concept of democracy that equates democracy with majority voting. Instead, they imply a more substantive, normative concept of democracy. ${ }^{27}$ When we advocate that a state promote democracy, we mean much more than the institution of free elections.

Instead of an institutional model that evaluates whether the institutions of democracy exist from an empirical standpoint, I adopt a normative approach proposed by Jürgen Habermas, who defines democracy in terms of the procedure used to arrive at decisions. The idea of a procedural model of democracy is that it has procedures in place that make it possible for a pluralist society (that is, a society not bound by a particular idea of the good) to produce rational outcomes that reflect the reasoned choices of individuals. Habermas describes this model as follows:

According to discourse theory, the success of deliberative politics depends not on a collectively acting citizenry [as in the communitarian model] but on the institutionalization of the corresponding procedures and conditions of communication, as well as on the interplay of institutionalized deliberative processes with informally developed public opinions. ${ }^{28}$

The procedural model presented by Habermas states that democracy exists where everyone affected by a decision has access to a discourse intended to solve a particular problem or address a particular issue. The procedures that structure this discourse ensure that

25 Ibid. at $10-12$.

26 On the cultural specificity of the concept of the rule of law, which is closely related to democracy, see Graham Mayeda, “Appreciate the Difference: The Role of Different Domestic Norms in Law and Development Reform; Lessons from China and Japan” (2006) 51 McGill L.J. 547. For the contrasting view that an institutional approach allows for cultural variants, see Ronald J. Daniels \& Michael Trebilcock, “The Political Economy of Rule of Law Reform in Developing Countries”(2004) 26 Mich. J. Int'l L. 99. See also Randall Peerenboom, “Competing Conceptions of Rule of Law in China,” in Randall Peerenboom, ed., Asian Discourses of Rule of Law: Theories and Implementation of Rule of Law in Twelve Asian Countries, France and the U.S. (London: RoutledgeCurzon, 2004) 113.

$27 \quad$ Supra note 20 at 618-19.

28 Jürgen Habermas, Between Facts and Norms: Contributions to a Discourse Theory of Law and Democracy, trans. by William Rehg (Cambridge: Massachusetts Institute of Technology Press, 1996) at 298 . 
it unfolds in a rational and reasonable way, and its orientation toward a consensus ensures that the outcome of the process is acceptable to all even if the result is not espoused by each participant. ${ }^{29}$ A procedural model of democracy differs from rational choice models in which individuals seek to promote their well-being and strategically build coalitions of power that can bargain with each other in a sort of “democratic market." Instead, deliberative democracy uses as its model a procedure for ensuring that the outcomes of the democratic process are rational and could be reasonably accepted by all of the participants. ${ }^{30}$

The advantage of the deliberative model for my purpose is that it sees a specific role for the law. The law - especially the constitution — provides a set of norms about the type of reasons that can be validly used in the public forum. As Habermas explains, "constitutional principles [provide] a consistent answer to the question of how the demanding communicative forms of democratic opinion- and will-formation can be institutionalized."31 If the deliberative procedure contained no such norms, then a racist decision taken by means of a consultative process between citizens would be democratic even though it discriminated against some of the participants. However, such decisions are excluded by the structure given to democratic debate by constitutional norms of equality. Because Habermas finds a role for law in this way, the model is particularly well-suited to evaluating the role of the international investment regime in promoting democracy.

As well, because the deliberative model is normative, it overcomes some of the difficulties of using a purely formal or institutional model of democracy. The fact that the model has normative content has two advantages. First, it makes it possible to separate out functioning democracies from "feckless" democracies - that is, we can identify those democracies that are producing democratic outcomes and those in which the institutional paraphernalia of democracy exists, but the outcomes do not reflect the reasoned views of citizens. Second, a normative model provides indicia that can be used across cultures: a country may be democratic on this view although it lacks Western hallmarks of democracy (for example, a democratically elected Parliament). Of course, this is not to say that the deliberative model is value-neutral. Clearly it is not; it is still principally a liberal model, and the values enshrined in it are derived from Western political experience and philosophy.

A final aspect of democracy is essential to the development context - this is the role of difference in deliberative democracy. It is implicit in the model of deliberative democracy that I have briefly described that no truly democratic decision can be made if the views of all groups are not articulated in the public forum. But as Iris Marion Young points out, more

29 The orientation toward a consensus does not mean that there must be consensus at the end of the deliberation. Joshua Cohen explains why the decision of a majority might still be acceptable to all in a deliberative democracy: "[E]ven if there is disagreement, and the decision is made by majority rule, participants may appeal to considerations that are quite generally recognized as having considerable weight, and as a suitable basis for collective choice, even among people who disagree about the right result: when participants confine their arguments to such reasons, majority support itself will commonly count as reason for accepting the decision as legitimate": Joshua Cohen, "Procedure and Substance in Deliberative Democracy” in James Bohman \& William Rehg, eds., Deliberative Democracy: Essays on Reason and Politics (Cambridge: Massachusetts Institute of Technology Press, 1997) 407 at 414. For a concrete articulation of a deliberative model, see Joshua Cohen, "Deliberation and Democratic Legitimacy” in Bohman \& Rehg, ibid., 67.

$31 \quad$ Supra note 28. 
than this is needed. Different groups must be given a voice, but the groups must also be willing to modify their own positions in response to the articulation of a different view. ${ }^{32}$ Young describes this by saying that "participants in the discussion must develop a more comprehensive and objective account of the social relations, consequences of action, and relative advantage and disadvantage, than each begins with from their partial social perspective.”33 A deliberative model of democracy thus provides a rich alternative to the institutional view, which claims that a democracy can be identified if certain institutions such as free speech and free elections exist. Instead, a deliberative model is animated by the norms of participation, rational deliberation, and openness to differences of opinion.

The model of deliberative democracy that I have set out above can be used to evaluate whether IIAs and arbitral decisions interpreting these agreements promote or detract from democracy. An IIA is compatible with democracy if the norms contained in it provide reasons for abridging the rights and entitlements of the nationals of the states party to the agreement that are recognized as acceptable in the public forum. An arbitral decision interpreting an IIA will promote democracy if the norms on which it relies are acceptable in the public forum of the states that are party to the agreement. However, two further criteria must be met by arbitral decisions: first, they must show reasonable deference to the decisions of state parties arrived at through deliberative democratic processes; second, following Young, they must promote "a more comprehensive and objective account of the social relations, consequences of action, and relative advantage and disadvantage, than each begins with from their partial social perspective." ${ }^{34}$ In other words, in seeking a just solution, rather than the vindication of the interests of one group over another, tribunals should be open to "learning from the social perspectives of people positioned differently in structures of power, resource allocation, or normative hegemony." ${ }^{35}$

\section{INTERNATIONAL INVESTMENT AgREEMENTS Can Limit The Policy Space of Home States}

Generally speaking, an IIA, like any international treaty, poses a threat to democracy because it creates a regime of treaty law whose norms have not been submitted to debate in the public sphere at either the international or the national level. Ideally, the democratic legitimacy of an international legal regime is submitted to the test of democratic legitimacy through a debate in the legislature or other approval process before ratification. However, this process is less useful as a democratic touchstone with the increasing shift in international law away from the sovereignty of nation-states on the international stage. As the sphere of state sovereignty decreases, so too does the importance of national democratic decisionmaking. Another factor contributing to the democratic deficit at the international level is the increasing recognition of individual human rights in the absence of a cosmopolitan world.

32 Iris Marion Young, “Difference as a Resource for Democratic Communication” in Bohman \& Rehg, supra note 29, 383 at 385, 399. For an articulation of a view of democracy that does not collapse into identity politics nor require the abandonment of different interest positions, see James Bohman, Public Deliberation: Pluralism, Complexity, and Democracy (Cambridge: Massachusetts Institute of Technology Press, 1996).

$33 \quad$ Young, ibid. at 385.

Ibid.

Ibid. at 401. 
As Immanuel Kant noted, an effective human rights regime requires a global cosmopolitan society because only such a society is able to legitimately create and enforce such rights. ${ }^{36}$ Habermas makes a similar point:

For actionable rights to issue from the United Nations Declaration of Human Rights, it is not enough simply to have international courts; such courts will first be able to function adequately only when the age of individual sovereign states has come to an end through a United Nations that can not only pass but also act on and enforce its resolutions. ${ }^{37}$

If we are not creating a global cosmopolitan society with its own democratic public forum, and yet at the same time we are eroding state sovereignty - the domain of democratic decision-making - then overall, we are reducing the relevance and reach of democracy.

From a formalist perspective, it is also clear that international law does not in and of itself promote democracy. Although domestic legislatures may have the ability to approve international agreements before they are ratified, they cannot suggest amendments to the treaty, although reservations might be proposed. ${ }^{38}$ A country cannot defend itself against a breach of a treaty by claiming that its internal law forbids performance of the obligation. ${ }^{39}$ States cannot derogate from jus cogens despite the democratically held views of their legislatures. ${ }^{40}$ And where a state's acts are consistently contrary to the acts of other states and are outliers in state practice, they can be in violation of customary international law. Developing countries in particular have raised concerns about their exclusion from participation in the shaping of international law. ${ }^{41}$ The history of colonialism has ensured that the normative foundation of international law is based in Western European norms and values. ${ }^{42}$ All these factors point to the danger that international law is not necessarily supportive of democracy. It is thus necessary for international law regimes to be designed to support, rather than to detract, from democracy.

Apart from the general observation that the use of international law has the potential to undermine democratic practices by holding states responsible for actions taken through the deliberative democratic processes of the state, ${ }^{43}$ there are also specific aspects of IIAs that

36 Immanuel Kant, “Perpetual Peace: A Philosophical Sketch” in Hans Reiss, ed., trans. by H.B. Nisbet Kant: Political Writings, 2d ed. (Cambridge: Cambridge University Press, 1991) 93.

$37 \quad$ Supra note 28 at 456 [footnotes omitted, emphasis in original].

$38 \quad$ M.C.W. Pinto, "Democratization of International Relations and Its Implications for Development and Application of International Law” in Najeeb Al-Nauimi \& Richard Meese, eds., International Legal Issues Arising under the United Nations Decade of International Law (The Hague: Kluwer Law International, 1995) 1249 at 1263-65.

39 Vienna Convention on the Law of Treaties, 23 May 1969, 1155 U.N.T.S. 331, arts. 27, 46 (entered into force 27 January 1980).

$40 \quad$ Ibid., art. 53.

41 See Declaration on the Establishment of a New International Economic Order, GA Res. 3201 (S-VI), UN GAOR, 6th Sess., UN Doc. A/RES/S-6/3201 (1974).

42 Antony Anghie, Imperialism, Sovereignty and the Making of International Law (Cambridge: Cambridge University Press, 2004). See also M. Sornarajah, The International Law on Foreign Investment, $2 \mathrm{~d}$ ed. (Cambridge: Cambridge University Press, 2004) at 371.

43 On the issue of the liability of states for the legislation they enact, Ian Brownlie states: "[i]n some circumstances legislation could of itself constitute a breach of a treaty provision and a tribunal might be requested to make a declaration to that effect”: Ian Brownlie, Principles of Public International Law, 6th ed. (Oxford: Oxford University Press, 2003) at 35. Sir Gerald Fitzmaurice states that when a state 
have the potential to undermine democracy. The most obvious of these are the provisions on expropriation and fair and equitable treatment. Since most IIAs contain very similar provisions, I will discuss them in a general way, rather than assessing particular agreements.

\section{A. EXPROPRIATION}

Expropriation has been defined as "the coercive appropriation by the State of private property, usually by means of individual administrative measures." ${ }^{44}$ It can be either direct or indirect. ${ }^{45}$ In the municipal law of most states, the government has the right to "take" the property of its nationals, and at times, this taking can occur without compensation for the property owner. For instance, in Keystone Bituminous Coal Association v. DeBenedictis, the United States Supreme Court held that where government regulates an individual's property for the purpose of achieving certain valid public purposes, the regulation will not constitute a compensable taking. ${ }^{46}$ Similarly, in Canadian law, if the government uses clear wording in a legislative enactment, then it can expropriate without paying compensation. ${ }^{47}$

Most IIAs contain an expropriation clause that requires the following:

(1) The expropriation must be for a public purpose;

(2) the expropriation must occur in a non-discriminatory manner;

(3) the expropriation must occur in accordance with due process of law; and

(4) compensation must be paid.

The protection provided to the investor by expropriation clauses is increased by broad definitions of "expropriation." These define expropriation as including direct and indirect expropriation, as well as acts "tantamount” to expropriation. As a result, IIAs provide protection against regulatory or "creeping" expropriations. In cases of creeping expropriation, if the value of an investor's property has diminished, an expropriation may be found even if the investor can still enjoy the use of her property.

adopts legislation contrary to its international obligations, "[i]n some cases the legislation itself undoubtedly constitutes the breach — as for instance if a law is passed expropriating foreign property without provision for adequate compensation, or if there were legislation denying to foreigners the right to appear in the Courts": Sir Gerald Fitzmaurice, "The General Principles of International Law Considered from the Standpoint of the Rule of Law” (1957) 92 Rec. des Cours 1 at 89 [emphasis in original].

44 Lauder v. Czech Republic (2001), 14:3 W.T.A.M. 35 at para. 200, (UNCITRAL Arbitration Proceedings).

45 Indirect or "creeping" expropriation is caused by a "measure that does not involve an overt taking, but that effectively neutralizes the enjoyment of the property": ibid.

Keystone Bituminous Coal Association v. DeBenedictis, 480 U.S. 470 at 497 (1987).

Technically speaking, the cases proceed by finding that there is no unconstitutional taking in the circumstances of the case. Florence Mining Co. Ltd. v. Cobalt Lake Mining Co. Ltd. (1909), 18 O.L.R. 275 at 279 (C.A.); Attorney-General v. De Keyser's Royal Hotel, Ltd., [1920] A.C. 508 at 542 (H.L.); Manitoba Fisheries Ltd. v. The Queen (1978), [1979] 1 S.C.R. 101 at 118; Authorson v. Canada (A.G.), 2003 SCC 39, [2003] 2 S.C.R. 40 at para. 53. 
IIA expropriation clauses have the potential to undermine democracy in two ways. First, unlike in Canadian and U.S. law, most IIAs do not provide exceptions that allow the state to expropriate without paying compensation. They thus do not recognize the legitimacy of a decision made by the citizens of the host state to exempt the state from providing compensation when it expropriates in the public interest. To use the example of Vivendi, under the Argentina-France BIT, it was not possible for the government of Tucumán to decide that it would not compensate the operator of the water utility when, to pursue a public purpose, it reduced the value of the concession in order to address the high fees charged by the utility for an essential public service. ${ }^{48}$

The limitation of the policy space of host states arises from three aspects of the expropriation provisions of IIAs: the definition of expropriation in IIAs is too broad, the state is never exempt from compensation for expropriations that are in the public interest, and the standard of compensation, when an expropriation is found, is too high.

Let us begin with the definition of expropriation. Rosalyn Higgins, writing 26 years ago, noted that at that time regulatory or creeping expropriation that did nothing more than diminish the value of investments did not constitute a compensable taking in international law: "The tendency [among international tribunals] is for a diminution in value to remain uncompensated, so long as rights of use, exclusion and alienation remain." 49 However, the case is very much different today. For instance, in the Vivendi case, the renegotiated concession agreements diminished the value of the agreements, but CAA retained the rights of use, exclusion, and alienation. What was lost was an expectation of a certain level of profit. Nevertheless, the ICSID Tribunal found that there was a compensable expropriation under the BIT. Admittedly, subsequent actions of the provincial authorities prevented CAA from collecting the monies owed to it by customers. But these actions followed from CAA's withdrawal from the concession. The Tribunal was of the view that the provincial authorities forced CAA to terminate the concession:

Here, the Province's actions — from the very opening months of the concession, continuing through its wrongful regulatory action and culminating in the unilateral amendments to the 8 April Agreement — had the necessary consequence of forcing CAA to terminate the Concession Agreement. ${ }^{50}$

The Tribunal was clearly of the view that the provincial authorities were wrong to insist on the renegotiation of the original concession, and that because CAA was right to insist on adhering to the initial agreement, its loss of the profits that it had expected under that

Supra note 1.

49 Rosalyn Higgins, "The Taking of Property by the State: Recent Developments in International Law" (1982) 176 Rec. des Cours 259 at 271, 278. See also Andrew Newcombe, "The Boundaries of Regulatory Expropriation in International Law” (2005) 20 ICSID Rev. 1 (if the state has not arbitrarily confiscated property (unless this confiscation is the valid exercise of a state police power to protect public order or morals, human health, or the environment) or failed to abide by contractual commitments on which the investor was relying, the appropriate test for an expropriation should be whether the state appropriated the investor's property. In his view, finding an expropriation based on whether the investor has been deprived of the full benefit of its investment casts the net too broadly. The test should be about "appropriation" rather than "deprivation”). 
agreement was an expropriation. ${ }^{51}$ This was not the proper inquiry. The Tribunal should not have focused on whether the concession was rendered less profitable because it was ultimately forced to give up the concession. Instead, it should have inquired into whether the renegotiated concession, which permitted a rate increase of 35 percent, ${ }^{52}$ would have rendered its enterprise so unprofitable that one could say that it had been deprived of its "rights of use." On this view, the intransigent party would have been CAA, which refused to renegotiate the concession, and not the state, which promoted renegotiation.

In addition to providing an overly broad definition of expropriation, IIAs rarely alleviate the host state from the need to pay compensation for a state-sanctioned expropriation. This is a departure from the international law of expropriation, which exempts states from compensating investors when the government taking was in pursuit of an important public interest. For instance, art. 10(5) of the Draft Convention on the International Responsibility of States for Injuries to Aliens identified a number of cases in which compensation need not be paid for a government taking:

\footnotetext{
An uncompensated taking of property of an alien or a deprivation of the use or enjoyment of property of an alien which results from the execution of the tax laws; from a general change in the value of currency; from the action of the competent authorities of the State in the maintenance of public order, health, or morality; or from the valid exercise of belligerent rights; or is otherwise incidental to the normal operation of the laws of the State shall not be considered wrongful. ${ }^{53}$
}

Franck supports the existence of a distinction between compensable and non-compensable takings. In his view, there should be a distinction

\footnotetext{
between a general taking in pursuance of a nationwide social policy intended to achieve industrial reform or redistribute income ... and an ad hoc taking of one property. The former can be viewed as analogous to certain other redistributive governmental takings, such as general taxation, for which compensatory remedies are not provided by international law. ${ }^{54}$
}

Most IIAs today do not distinguish between takings that serve a valid government purpose and those that do not, and this has had a significant effect on developing countries. We can see this restriction at work in the case of the Argentina-France BIT at issue in Vivendi. Because it required compensation for takings without discriminating between those aimed at valid government purposes and those that were not, had the water turbidity that occurred while CAA operated the water utility posed a threat to public health, Argentina might have been obliged to compensate the utility for any regulations that diminished the value of the investor’s investment. Similarly, had high water tariffs had an impact on access to water,

$51 \quad$ Ibid

$52 \quad$ Ibid. at para. 7.4.42.

53 Draft Convention on the International Responsibility of States for Injuries to Aliens in Louis B. Sohn \& R.R. Baxter, "Responsibility of States for Injuries to the Economic Interests of Aliens" (1961) 55 A.J.I.L. 545 at 554 [Harvard Draft Convention on International Responsibility].

54 Thomas M. Franck, Fairness in International Law and Institutions (Oxford: Clarendon Press, 1995) at 462 [footnotes omitted]. For a development of this distinction, see also Derek William Bowett, "State Contracts with Aliens: Contemporary Developments on Compensation for Termination or Breach" (1988) 59 Brit. Y.B. Int'l L. 49 at 72-74. 
which is essential for maintaining human health, under the existing BIT, Argentina would have been powerless to act without compensating CAA for the loss of revenue from its concession. Indeed, in Vivendi, the Tribunal held that the provision of the Argentina-France BIT protecting French nationals against expropriation would be violated if the investor were not compensated regardless of whether the government had a valid public purpose. ${ }^{55}$

If the same case had been evaluated under Canadian law, the Tribunal in Vivendi would have had to consider more than whether a taking had taken place and whether the host state had provided compensation. The Tribunal would have also had to consider whether the Tucumán authorities had a valid public purpose in depriving the foreign investor, whether there was a clear legislative intent to do so, and whether the intent was to expropriate without compensation. However, all that the Tribunal required Vivendi Universal to do in order to obtain compensation was to demonstrate a substantial loss in value of its investment that was not compensated. In my view, international law should be brought into line with the domestic rules regarding expropriation of countries like Canada and the U.S.

Although the Tribunal in Vivendi claimed to be following the law on indirect expropriation as set out in the decisions of international tribunals, it did not properly interpret the rules of customary international law relating to expropriation. As I have already indicated, art. 10(5) of the Harvard Draft Convention on International Responsibility provides that no compensable taking exists where the state was pursuing a number of legitimate public purposes, including taxation and the maintenance of public order, health, or morality. ${ }^{56}$ The Tribunal in Vivendi invalidates these well-recognized exceptions to expropriation by claiming that any taking must be presumed to be compensable. This seems to violate the interpretation of expropriation in customary law as contained in the Harvard Draft Convention on International Responsibility. However, in my opinion, if the articles correctly state customary international law, they still do not go far enough to protect the state's right to regulate. The state's ability to regulate should be expanded to permit the achievement of other legitimate objectives, such as the promotion of public welfare. ${ }^{57}$ If the government objectives are legal in the host state, then as long as the government achieves them by observing due process and does not arbitrarily target particular investors, government action should not be found to be a compensable expropriation. ${ }^{58}$ Of course, the state cannot have carte blanche to regulate the investments of foreign investors for the achievement of inconsequential and unimportant ends. An international investment tribunal should thus be able to review whether the government goal is pressing and substantial, and whether the

Supra note 1 at para. 7.5.21.

Supra note 53.

See Newcombe, supra note 49 at 22, 39-40. Newcombe is of the view that no compensation is due in international law for government regulation that is reasonably necessary to protect public health, safety, morals, or welfare, for non-discriminatory government regulation for the purpose of taxation, or the achievement of the police powers of the state. See also George H. Aldrich, "What Constitutes a Compensable Taking of Property? The Decisions of the Iran-United States Claims Tribunal” (1994) 88 A.J.I.L. 585 at 609.

58 See also Sornarajah, supra note 42 at 385, who asserts that " $[\mathrm{t}]$ he starting point must always be that the regulatory interference is presumptively non-compensable.” He goes on to state that the "presumption against compensation ... is strengthened where the public interests are so dominant as to overwhelm individual interests. It is weakened where there is discrimination that cannot be explained in a legitimate manner. It is weakened also where the exercise is not accompanied by due process and other procedural safeguards that amount to a denial of justice in terms of international law” (at 385-86). 
means used by the government are reasonably necessary to achieve the end it claims to be pursuing. ${ }^{59}$

One could object that Tucumán was within its right to object to privatization and expropriate the investment as long as it provided compensation. But property owners are not necessarily entitled to compensation. Rather, the question of when to compensate investors is an issue to be discussed in the public forum because the ability to expropriate is an important policy tool for governments during a period of economic development. For instance, throughout the nineteenth and early twentieth centuries, a period of rapid economic growth in North America, the U.S. refused compensation for certain types of expropriation in order to increase growth. ${ }^{60}$ The American jurisprudence on expropriation in the mining sector is a good example of this: no compensable taking was found where the underlying purpose of the taking was the development of valuable natural resources. Developing countries are entitled to make a decision about the appropriate balance between the protection of private and public property interests, and these decisions should be respected by limiting the definition of expropriation so that states can pursue their objectives as long as their actions are not arbitrary or discriminatory. The limits on the state's right to regulate should be set by an assessment of the pressing and substantial nature of its objective and the necessity of the measures it has implemented for achieving this objective.

In addition to the breadth of the definition of expropriation in most IIAs and the issue of whether compensation should be provided, the question of the amount of compensation required for expropriation also has an impact on the flexibility of a developing country to implement public policies. If compensation is required, the amount of this compensation might have an impact on whether the state can afford to implement its law, regulation, or policy. Increasingly, IIAs require that an expropriated investor receive "prompt, adequate and effective compensation." 61 However, lower standards are possible, including "just compensation,” “equitable compensation,” or “appropriate compensation.” Some model IIAs provide for customary international law standards to be applied for assessing the amount of compensation. ${ }^{62}$ Developing countries who wish to minimize their exposure to high compensation awards should consider adopting lower standards of compensation. If they choose to adopt the customary international law standards, they should be aware of the controversy over the degree of compensation required by international law. As M. Sornarajah points out, tribunals that have maintained that full compensation is required for any

59 See Newcombe, supra note 49 at 40 (The assessment of the necessity of the measure should not involve the tribunal in a substantive review of the viability of other alternatives to expropriation. Tribunals should defer to the judgment of national governments in this regard).

60 Sornarajah discusses how the requirement of compensation and the degree of compensation required differs as the country becomes more industrialized. He points out that " $[\mathrm{t}] \mathrm{his}$ course of development indicates that in any given society a balance has to be struck between individual rights in property and the public interest and that balance can only be struck by each state having regard to its own developmental needs": supra note 42 at 450.

61 See Canada's Foreign Investment Promotion and Protection Agreement (FIPA) Model adopted in 2004, online: Foreign Affairs and International Trade Canada <http://www.international.gc.ca/tradeagreements-accords-commerciaux/assets/pdfs/2004-FIPA-model-en.pdf>; the U.S. Model Bilateral Investment Treaty (BIT), online: U.S. Department of State <http://www.state.gov/documents/ organization/38710.pdf>.

62 See e.g. Norway Model Bilateral Investment Treaty, online: Investment Treaty Arbitration <http://ita.law.uvic.ca/documents/NorwayModel2007.doc>. 
government taking have arrived at this view by applying the standard of full compensation demanded for unlawful expropriations to all government takings. ${ }^{63}$ However, it is not evident that the standard for unlawful expropriations should apply also to lawful expropriations, since this limits the scope of developing countries to make policies in regard to property rights.

Was the taking in Vivendi an expropriation for which there should be compensation? One interpretation is that CAA, Vivendi Universal's Argentine subsidiary, was the subject of an expropriation for which compensation is owed because the Tucumán government had failed to live up to the commitments it had made in the concession agreement with CAA, and the investor had been denied the ability to use its property by the acts of the Province subsequent to its withdrawal from the concession. Having withdrawn from the agreement, the Tucumán authorities made it impossible for the concessionaire to recover the amounts owed to it by its customers while it still operated the concession. In my view, the government had the right to renegotiate the concession if the privatization was widely opposed by residents of the province, and if the privatization demonstrably affected public welfare in a serious and negative way. Of course, the state could not act arbitrarily or in a discriminatory manner. However, the Tribunal did not consider any evidence relevant for determining if the provincial authorities were pursuing their own self-interest or seeking to act on a publicly held view about the privatization that resulted from the exercise of democratic processes.

Furthermore, it seems clear that CAA was denied due process of law. This implicates democracy because CAA's claims should be given a voice in the public forum and due process involves procedural mechanisms to ensure that this occurs. However, the normative content of due process should be assessed through a comparison of the interpretation of due process rights in the host state with international standards of due process. The international understanding of democratic due process should not be applied in a vacuum to invalidate the process observed by the host state without first interpreting the state's process in the context of domestic understandings of fairness. ${ }^{64}$

\section{B. FAIR AND EQUiTABLE TREATMENT}

The requirement to provide fair and equitable treatment also has the potential to affect democracy. The purpose of provisions setting out minimum standards of treatment is to ensure that foreign investors are not treated in ways that all states recognize as unacceptable. Some IIAs ensure that foreign investors will be provided with treatment in accordance with what is called the "international law minimum standard." ${ }^{65}$ Others use the term "fair and equitable treatment," while still others use the language of fair and equitable treatment while identifying that this is intended to be equal to the minimum standard ${ }^{66}$ The principal concern in choosing between these standards is whether the standard is intended to protect the expectations of investors, and so provide compensation when investments are less profitable

Supra note 42 at 471.

For a better understanding of the importance of contextual interpretation for respecting principles of sustainable development, see Graham Mayeda, "International Investment Agreements Between Developed and Developing Countries: Dancing with the Devil? A Case Commentary on the Vivendi, Sempra and Enron Awards” (2008) McGill J.S.D.L.P. 189. Ibid.

See the Canadian FIPA Model and the U.S. Model BIT, supra note 61. 
than investors expected, or whether the standard merely requires treatment in accordance with the international minimum standard, which does not require compensation for expected future earnings.

The international minimum standard generally requires the following:

(1) States cannot engage in
(a) bad faith and arbitrary treatment of investors;
(b) wilful neglect of the interests of investors; or
(c) clearly unreasonable treatment of investors. ${ }^{67}$

(2) States must

(a) treat investors in accordance with due process (that is, through a fair and effective system of justice); ${ }^{68}$ and

(b) be duly diligent in preventing harm to investors.

Some commentators, and increasingly, investment tribunals have held that fair and equitable treatment imposes the following additional requirements:

(1) An obligation of vigilance and protection (that is, an obligation to exercise due diligence in protecting foreign investments);

(2) an obligation of transparency;

(3) an obligation of good faith, which includes an obligation to protect the basic expectations of investors created by the treaty; and

(4) an obligation to respect "autonomous fairness elements," which seems to include fairness obligations beyond those required by international law and that are generally recognized in the legal systems of states with well-developed legal systems. $^{69}$

Concerns about democracy arise primarily in regard to criterion three, the requirement to protect the basic expectations of investors.

Developing countries have come to grief as a result of the wide interpretation given to the standard of fair and equitable treatment by recent arbitral panels. In CMS Gas Transmission v. Argentina, the Tribunal found that Argentina had breached the principle by implementing regulations intended to control the economic meltdown it experienced at the end of the $1990 \mathrm{~s}$ 
and in the early part of the new millennium. ${ }^{70}$ These measures, which included pegging the peso to the U.S. dollar and refusing to increase gas tariffs in accordance with the U.S. Producer Price Index (PPI) (which resulted in decreased revenues as the peso was devalued), resulted in CMS Gas Transmission Company's (CMS) Argentine subsidiary losing 75 percent of its domestic tariff revenue. ${ }^{71} \mathrm{CMS}$ also argued that Argentine gas prices were depressed as a result of the government's actions, and that the depressed prices were an "effective subsidy benefiting the rest of the Argentine economy."72 The Tribunal agreed with CMS, who argued that "[The Government] breached its obligation of fair and equitable treatment by evisceration of the arrangements in reliance upon [which] the foreign investor was induced to invest" Parties to provide to international investments treatment that does not affect the basic expectations that were taken into account by the foreign investor to make the investment."74

The Tribunal interprets the principle of fair and equitable treatment in such a way as to protect the expectation of the investors while at the same time limiting Argentina's ability to deal with an economic crisis that had a serious impact on its citizens. If a state's measures enacted to deal with a profound economic upheaval affect the "expectations that were taken into account by the foreign investor to make the investment,"75 then the state will run afoul of its obligations under an IIA. This is a serious disincentive for the state to act in the public interest.

Government regulation is a risk that must be taken into account by any investor, be the investment domestic or international. The decision of who should bear the risk of government regulation is a decision for the citizens of a state, who must decide how to balance the protection of investors against the state's flexibility to adopt policies in the public interest that could limit the profitability of investors. States have frequently stated that they should not act as insurers for risky investments. ${ }^{76}$

The confusion over the degree of protection that a state must provide to a foreign investment arises in part through the use of different wording to capture the obligation. Some tribunals and commentators are of the view that the use of the wording "fair and equitable treatment" rather than citing the "minimum standard" implies the adoption of a new standard distinct from the minimum standard. ${ }^{77}$ Others have argued that the protection provided by the

CMS Gas Transmission v. Argentina (2005), 44 I.L.M. 1205 (International Centre for Settlement of Investment Disputes) [CMS Gas].

Ibid. at para. 70 .

Ibid. at para. 72.

Ibid. at para. 267, citing CME Czech Republic B.V. (The Netherlands) v. Czech Republic (2001), 14:3 W.T.A.M. 109 at para. 611 (UNCITRAL Arbitration Proceedings).

74 Ibid. at para. 268, citing Técnicas Medioambientales Tecmed v. United Mexican States (2004), 43 I.L.M. 133 at para. 154 (International Centre for Settlement of Investment Disputes).

75 Ibid.

$76 \quad$ Waste Management v. United Mexican States (2004), 43 I.L.M. 967 at para. 114 (International Centre for Settlement of Investment Disputes); see also Maffezini v. Kingdom of Spain (2000), 5 I.C.S.I.D. 419 at para. 64; Olguín v. Republic of Paraguay (2001), 6 I.C.S.I.D. 164 at paras. 72-75.

77 F.A. Mann, "British Treaties for the Promotion and Protection of Investments," Note, (1981) 52 Brit. Y.B. Int'l L. 241; Rudolf Dolzer \& Margrete Stevens, Bilateral Investment Treaties (The Hague: Martinus Nijhoff, 1995); Metalclad Corp. v. United Mexican States (2000), 13:1 W.T.A.M. 47 (International Centre for Settlement of Investment Disputes); Pope \& Talbot v. Government of Canada 
"minimum standard" is outdated, suggesting that greater protection ought to be afforded to foreign investors. ${ }^{78}$ Elsewhere, others have argued that the standard of fair and equitable treatment ought to be interpreted to be identical to the minimum standard. ${ }^{79}$

The safest course of action for a developing country that wishes to ensure it has sufficient policy flexibility is to adopt the international minimum standard in any IIA it negotiates rather than the standard of fair and equitable treatment, and to state the standard of protection that it understands to be required by the international minimum.

Of course, it is not just the provisions of IIAs that have the potential to limit democracy. Investment tribunals also have a responsibility to support democracy, and this entails interpreting IIAs so as to ensure greater policy space for democratic decision-making. I now turn to more specific ways in which investment tribunals limit democracy in developing countries.

\section{INTERNATIONAL INVESTMENT TRIBUNALS CAN UNDERMINE DEMOCRACY BY IGNORING THE NORMS AND VALUES OF DOMESTIC DEMOCRATIC FORUMS}

So far, I have argued that expropriation and equitable treatment clauses in IIAs have the potential to infringe democracy by limiting the ability of developing countries to implement policies arrived at through a deliberative democratic process. In this section, I address the question of whether and how investment tribunals should consider the reasons given by a host state for a legislative or regulatory change that has negatively affected an investor when considering whether the IIA has been breached. Should investment tribunals assess the reasonableness of a state's reasons for actions that negatively affect foreign investors, or should they be limited to considering whether the reasons were arrived at through democratic deliberation? What degree of deference should tribunals demonstrate toward the reasons provided by governments and the interpretations of laws, regulations, and rules provided by governments and national tribunals? As we will see, at the very least, tribunals should not second-guess decisions about the public interest if they are arrived at through a deliberative democratic process. I have specified that these decisions must be arrived at through a deliberative process because if the only indicia used to identify whether a decision was arrived at "democratically" is to evaluate whether it was made by elected officials, then it is

(2001), 13:4 W.T.A.M. 61 at para. 113 (NAFTA Ch. 11 Arbitration Tribunal).

Pope and Talbot v. Government of Canada (2002), 14:6 W.T.A.M. 44 at paras.59-60 (NAFTA Ch. 11 Arbitration Tribunal).

Graham Mayeda, "Playing Fair: The Meaning of Fair and Equitable Treatment in Bilateral Investment Treaties” (2007) 41 J. World Trade 273. See also Stephen Vasciannie, “The Fair and Equitable Treatment Standard in International Investment Law and Practice” (1999) 70 Brit. Y.B. Int’l L. 99 at 104; “O.E.C.D. Draft Convention on the Protection of Foreign Property” (1967) 7 I.L.M. 117; S.D. Myers v. Canada (2000), 15:1 W.T.A.M. 184 (UNCITRAL Arbitration Proceedings); Genin v. Republic of Estonia (2002) 17 ICSID Rev. 395; Loewen, supra note 68 at para. 128. Note that in the third S.D. Myers decision, the Tribunal noted the standard of "fair and equitable treatment," although identical to the international standard, could not forever be limited to the very narrow interpretation given to the minimum standard in L.F.H. Neer and Pauline Neer (U.S.A.) v. United Mexican States (1926) IV R.I.A.A. 61 (United Nations). 
obvious that the decisions of sham democracies or of corrupt officials will be given a democratic status that they do not deserve.

\section{A. Second-guessing The Public InTERest}

To set the stage, the first issue is whether tribunals are involved in this kind of secondguessing. The evidence suggests that tribunals do evaluate the reasons given by the state for the alleged breach rather than evaluating whether they were arrived at democratically. For instance, in Vivendi, the investor argued that the actions of Tucumán authorities were not the result of democratic decision-making, but of the corrupt use of public office. The Tribunal described the acts as "sovereign acts designed illegitimately to end the concession or to force its renegotiation." 80 As well, the acts were not "legitimate regulatory responses to CAA's failings." ${ }^{81}$ The Tribunal gave little weight to the fact that the renegotiated agreement was reviewed by the provincial legislature and, had CAA not ended the agreement, it would have been approved by that elected assembly. Admittedly, the renegotiated agreement contained 70 changes to which the concessionaire had not agreed. But this did not obviate the need for an analysis of the democratic legitimacy of the norms being reviewed. It was important for the Tribunal to consider the democratic dimension even if its ultimate conclusion would be to find Tucumán's actions unlawful. Also, the Tribunal did not consider whether the decision to renegotiate the concession agreement without compensating the concessionaire was the result of a deliberative democratic process.

Although there was no evidence in the case that Tucumán authorities were motivated by personal interests as opposed to legitimate concerns about privatization, public health, and the cost of water to the public, the Tribunal nonetheless imputed wrongdoing from the fact that there was a widespread objection to the privatization among Tucumán officials. Although the Tribunal implied that the government officials of Tucumán, both elected and unelected, were motivated by improper purposes, it did not articulate what these purposes were. In fact, the Tribunal accepted the reasons for concern given by the officials - a growing opposition to privatization and the increase in the cost of water as a result of the privatization — but nevertheless imputed unspecified wrongdoing. The Tribunal thus failed to consider whether the reasons motivating the officials to act were justifiable in a democratic forum.

In my view, if the allegation is essentially one of corruption against the local officials, then this should be made explicit, and the reasons for the impropriety of their motives should be given. Furthermore, the alleged corruption should be assessed based on the standard current in the democratic public forum of the relevant jurisdiction rather than standards current in some other forum. In other words, tribunal members should not use norms from other cultures and contexts to evaluate the reasons presented by the host country for changing the laws and regulations affecting the investor. However, if the allegation is that the government decision is a sham and that it is not in the public interest, then the tribunal must give reasons to make its case. In the case of Vivendi, it is not obvious to me that an objection

$80 \quad$ Supra note 1 at para. 7.5.22.

Ibid. 
to privatization and the doubling of the cost of an essential service is an illegitimate public interest that demonstrates the bad faith of Tucumán authorities.

\section{B. INTERPRETATION OF NATIONAL LAW BY INTERNATIONAL TRIBUNALS}

Related to the previous issue is the question of the legitimacy of international investment tribunals providing their own interpretation of the national law of the host state. To illustrate the problem, in CMS Gas, Argentina argued that its treatment of foreign investors did not constitute a violation of the U.S.-Argentina BIT, because domestic courts have interpreted the protection offered to property in the Argentine Constitution as not being absolute. Instead, it argued that "State intervention in the regulation of individual rights is justified, provided such intervention is both legal and reasonable when factoring in social needs." 82 In arriving at its conclusion that the BIT was breached, the ICSID Tribunal interpreted the Argentine Constitution. In finding that it had jurisdiction to decide the issue, the Tribunal interpreted arts. 27 and 31 of the Constitution relating to the incorporation of international law into Argentine law. ${ }^{83}$ It also held that, contrary to Argentina's contentions, "the Constitution carefully protects the right to property." ${ }^{\text {"4 }}$ Later in the judgment, the Tribunal goes on to interpret Argentine law in order to determine whether there was a breach of the treaty. In its view, since there were other legal measures that Argentina could have taken that would not have breached its contractual obligations with the foreign investor, Argentina breached its contractual commitments, thus giving rise to international liability. ${ }^{85}$

International tribunals frequently have the jurisdiction to interpret national law. ${ }^{86}$ Also, some international treaties specifically permit international tribunals to interpret and apply national law to resolve a dispute. For instance, art. 42 of the Convention on the Settlement of Investment Disputes Between States and Nationals of Other States empowers arbitral tribunals to apply the law of the contracting state in the absence of an agreement between the parties as to the applicable law. ${ }^{87}$ This has been interpreted as permitting the ICSID tribunals to apply national law in conjunction with international law or to apply international law alone as the circumstance requires. ${ }^{88}$ However, the question remains as to the circumstances in which international tribunals can interpret national law and the appropriate standard of review.

Supra note 70 at para. 113.

Ibid. at paras. 119-20.

Ibid. at para. 121.

Ibid. at paras. 238-39.

See e.g. Sharif Bhuiyan, National Law in WTO Law: Effectiveness and Good Governance in the World Trading System (Cambridge: Cambridge University Press, 2007) at 100-101: under the Marrakesh Agreement Establishing the World Trade Organization, 15 April 1994, 1867 U.N.T.S. 154 (entered into force 1 January 1995), a member can challenge a "measure” taken by a party that infringes the treaty. Although the term "measure" is not defined in the WTO treaty, it is defined in the General Agreement on Trade in Services, 15 April 1994, 1869 U.N.T.S. 183 (entered into force 1 January 1995), art. XXVIII(a), as including "any measure by a Member, whether in the form of a law, regulation, rule, procedure, decision, administrative action, or any other form.” This indicates that WTO panels have the jurisdiction to review national legislation.

18 March 1965, 575 U.N.T.S. 159 (entered into force 14 October 1966).

Wena Hotels Ltd. v. Arab Republic of Egypt (2002), 41 I.L.M. 933 at para. 40 (International Centre for Settlement of Investment Disputes); CMS Gas, supra note 70 at para. 116. 
There is some uncertainty as to the practice of international courts in regard to interpreting municipal law. The Case Concerning Certain German Interests in Polish Upper Silesia ${ }^{89}$ is often understood as deciding that an international tribunal considers municipal law as a fact to be taken into account in determining if a state has breached its international legal obligations. International tribunals thus do not interpret or apply municipal law to settle a dispute unless parties have agreed that this should occur. ${ }^{90}$ However, some authors challenge this interpretation, arguing that it is a function of international tribunals to interpret municipal law. ${ }^{91}$ Others take a middle position, arguing that although the national laws of a state are to be considered as facts, they are facts with normative content, and so a certain degree of interpretation is required in order to establish their meaning as matters of fact. ${ }^{92}$

Views also differ as to the deference that international tribunals must show to the interpretations of national law by domestic courts. Ian Brownlie states that the interpretation of national laws by national tribunals is binding on international courts. ${ }^{93}$ However, Sharif Bhuiyan suggests that deference will not always be shown. For instance, if the jurisprudence of national courts is divided, then international courts may have to interpret national law to determine if a breach of international law has occurred. ${ }^{94}$ In the World Trade Organization (WTO) context, tribunals have held that in assessing the decisions of domestic tribunals, consideration must be given to the hierarchy of domestic courts (whether the decision was rendered by a lower court, appeal court, or ultimate appeal court), the level of detail in which the issue was considered by the court, whether the decision was interlocutory or final, and so on. The Panel in United States - Anti-Dumping Act of 1916 noted that WTO panels could also assess the arguments provided by various national courts and adopt an interpretation that takes into account whether the reasoning of the domestic courts is convincing and the prevalence of the interpretation among domestic courts. ${ }^{95}$ Although it might appear that WTO tribunals do not defer to the decisions of domestic courts, the rhetoric of these tribunals is that they interpret national law to establish its meaning as $a$ matter of fact, rather than interpreting national law de novo as a national court would. ${ }^{96}$

If the ICSID Tribunal's interpretation of its jurisdiction to interpret and apply the national law of the host state is correct and these tribunals can provide their own interpretations of the national law of the host state, this poses serious difficulties from the point of view of deliberative democracy. Similar problems also arise with the interpretation of the decisions

(1926), P.C.I.J. (Ser. A) No. 7.

See Brownlie, supra note 43 at 8. See also ibid. at 19.

C. Wilfred Jenks, The Prospects of International Adjudication (London: Stevens \& Sons, 1964) at 600. Bhuiyan, supra note 86 at 215-16.

Brownlie, supra note 43 at 39; Case Concerning the Payment of Various Serbian Loans Issued in France (1929), P.C.I.J. (Ser. A) No. 20 at 46; Case Concerning the Payment in Gold of the Brazilian Federal Loans Contracted in France (1929), P.C.I.J. (Ser. A) No. 21 at 124 [Brazilian Loans]; Fisheries Case (United Kingdom v. Norway), [1951] I.C.J. Rep. 116 at 181, McNair J., dissenting; Nottebohm Case (Liechtenstein v. Guatemala), [1955] I.C.J. Rep. 4 at 28-29, Klaestad J., dissenting; Lighthouses Case Between France and Greece (1934), P.C.I.J. (Ser. A/B) No. 62 at 22.

Bhuiyan, supra note 86 at 223. See also Brazilian Loans, ibid.

United States - Anti-Dumping Act of 1916 (2000), WTO Doc. WT/DS136/AB/R at paras. 6.52-59, 6.134-62 (Appellate Body Report), online: WTO <http://docsonline.wto.org/gen_search.asp>.

Bhuiyan, supra note 86 at 243. See also India - Patent Protection for Pharmaceutical Protection and Agricultural Chemical Products (1997), WTO Doc. WT/DS50/AB/R at para. 66 (Appellate Body Report), online: WTO <http://docsonline.wto.org/gen_search.asp>. 
of WTO tribunals, which considers that these tribunals are permitted to interpret national legislation differently from domestic courts. Norms arrived at in a deliberative democracy are legitimate if they are based on reasons that all could accept in a forum oriented toward a consensus. National courts are a part of this deliberative process since their legitimacy depends on the use of norms acceptable in the public forum. But international courts and tribunals lack this legitimacy if they interpret domestic law rather than relying on the interpretations of this law given by domestic courts.

As I mentioned at the beginning of this section, the CMS Gas case provides an example of a tribunal interpreting national law that has the potential to undermine democracy. In that case, in deciding if Argentina had breached its obligations under the Argentina-France BIT, the Tribunal investigated whether Argentine law provided other means of dealing with its economic instability that would not affect investors. While such an investigation might legitimately fall within the competence of an international tribunal, it is not clear that the tribunal merely received interpretations of domestic law as facts. The wording of the decision and the lack of extensive references to expert opinions or the decisions of domestic courts suggests that the Tribunal interpreted the treaties on its own. A similar objectionable process was used in deciding whether the Tribunal had jurisdiction to decide the dispute, and in deciding what law (municipal, international, or both) should be applied to settle the dispute.

In my view, this procedure raises serious issues for the promotion of democracy. International courts are not part of the feedback loop that produces and refines democratically accepted norms in the host state. International courts lack legitimacy when interpreting the norms of domestic law. The effect of the decisions of international tribunals is often to impose policy decisions on countries by deciding whether an expropriation is in the public interest and by requiring full compensation for future profits. These policy decisions have redistributive consequences and developing countries should be aware of the potential negative impact they can have on democracy. The democratic legitimacy of international tribunals could be increased by appointing arbitrators with expertise in the law of the host state and by requiring arbitral tribunals to show greater deference toward the decisions of domestic courts interpreting the law applicable to the resolution of the conflict. ${ }^{97}$ Finally, if an investor is required to exhaust domestic remedies before requesting arbitration by an ICSID panel, this will ensure that domestic courts will have interpreted the relevant provisions of domestic legislation and minimize the need for an investment tribunal to choose a valid interpretation of domestic law from among those current in the reasons of national tribunals. 


\section{EXHAUSTION OF DOMESTIC REMEDIES}

IIAs do not uniformly require investors to seek remedies before domestic administrative tribunals and courts before submitting a claim to international arbitration. The Canadian and U.S. models do not contain provisions on the exhaustion of national remedies, although the Norwegian model does. ${ }^{98}$ From the point of view of promoting democracy, there are a number of benefits to requiring foreign investors to exhaust domestic remedies before submitting their complaint for resolution by an international investment tribunal. First, if an international tribunal arrives at a different interpretation of domestic law than domestic courts, this can give rise to a crisis of legitimacy for both courts. Second, unlike domestic courts, an international tribunal is not plugged into the domestic democratic forum. This means that international tribunals may not have access to norms validated in the domestic public sphere. It also means that a decision of an international tribunal that does not take into account the way that the domestic government has sought to balance the rights and interests of foreign investors against other public interests will, when it renders its decision, be imposing norms and values on the residents of the host state without having these norms vetted in the public forum. By requiring investors to exhaust domestic remedies, many of these deficiencies can be overcome.

Finally, Ronald J. Daniels argues that one of the main concerns with IIAs is that, by creating a separate treaty regime for foreign investors that does not require them to submit to domestic law, investors have no incentive to work with the host state to improve domestic legislation. ${ }^{99}$ Daniels uses this as an objection to IIAs in general. But by requiring the exhaustion of domestic remedies, a middle ground could be found that would both ultimately provide the protection of international law to investors and provide incentives for the investor to work with governments to create a favourable domestic investment environment, perhaps with the goal of one day obviating the need for an IIA. Having investors involved in improving domestic investment legislation clearly has benefits from the point of view of deliberative democracy since any changes to domestic legislation will have to be debated in the public forum, and the interests of investors and the public weighed in the balance of public opinion.

\section{Promoting Democracy by Imposing Duties on Home States AND INVESTORS TO KEEP INVESTORS ACCOUNTABLE}

A tremendous amount has been written about the benefits of imposing obligations on corporations investing in other countries and on home states to ensure that their nationals investing in foreign countries respect human rights, including labour rights and the rights of indigenous peoples, through the imposition of rules regarding corporate social responsibility. ${ }^{100}$ As a result of this extensive coverage of the issue, I will only address

Supra notes 61-62.

Ronald J. Daniels, "Defecting on Development: Bilateral Investment Treaties and the Subversion of the Rule of Law in the Developing World” (23 March 2004), online: Università Degli Studi Di Siena <http://www.unisi.it/lawandeconomics/stile2004/daniels.pdf>.

Steven R. Ratner, “Corporations and Human Rights: A Theory of Legal Responsibility” (2001)111 Yale L.J. 443 (on the imposition of international corporate social responsibility obligations directly on corporations); Simon Chesterman, "Oil and Water: Regulating the Behavior of Multinational 
imposing duties on home states and on investors from the point of view of the promotion of democracy.

By including provisions requiring foreign investors to comply with and promote international human rights standards and requiring home states to regulate their nationals investing in other countries, host states can ensure the accountability of foreign investors, and use IIAs to promote the international human rights that are supported in the democratic public forum. Also, for those states that lack the capacity to assess the impact of IIAs on their ability to implement policies arrived at through democratic processes, developing countries can include clauses in IIAs requiring the home states of investors to contribute resources to help in the evaluation of foreign investments. ${ }^{101}$ Accountability of private parties is supportive of democracy, and deliberative democracy in particular, because it ensures that decisions that affect the public are open to discussion in a public forum in which democratic norms are current.

\section{SUMMARY: LESSONS TO BE LEARNED FROM INTERNATIONAL INVESTMENET AGREEMENTS}

The lesson for developing countries to learn is that they need to provide provisions in their IIAs that permit them sufficient policy room to legislate in the public interest without running afoul of their international commitments and ensure that they are able to enforce the norms and values that are supported in their public forum. One way of doing this is by ensuring IIAs contain provisions that permit expropriation that has a legitimate public welfare goal. For instance, non-discriminatory regulatory actions by a party that are designed and applied to achieve legitimate public welfare objectives such as promoting or protecting the economic security of residents, public health, safety, internationally and domestically recognized labour rights, human rights, the rights of indigenous peoples, social justice, and the environment should not constitute expropriations. Provisions regarding the fair treatment of investors

Corporations Through Law” (2004) 36 N.Y.U. J. Int'l L. \& Pol. 307; Sarah Joseph, Corporations and Transnational Human Rights Litigation (Oxford: Hart, 2004); Jedrzej George Frynas \& Scott Pegg, eds., Transnational Corporations and Human Rights (Houndmills: Palgrave Macmillan, 2003); Nicola Jägers, Corporate Human Rights Obligations: In Search of Accountability (Antwerpen: Intersentia, 2002); Carlos M. Vázquez, “Direct vs. Indirect Obligations of Corporations Under International Law” (2005) 43 Colum. J. Transnat'l L. 927; Surya Deva, "Human Rights Violations by Multinational Corporations and International Law: Where from Here?” (2003) 19 Conn. J. Int’l L. 1; Mahmood Monshipouri, Claude E. Welch, Jr. \& Evan T. Kennedy, "Multinational Corporations and the Ethics of Global Responsibility: Problems and Possibilities” (2003) 25 Hum. Rts. Q. 965; Elliot J. Schrage, “Judging Corporate Accountability in the Global Economy” (2003) 42 Colum. J. Transnat'l L. 153; Logan Michael Breed, "Regulating Our 21st-Century Ambassadors: A New Approach to Corporate Liability for Human Rights Violations Abroad” (2002) 42 Va. J. Int'l L. 1005; Anita Ramasastry, “Corporate Complicity: From Nuremberg to Rangoon: An Examination of Forced Labor Cases and Their Impact on the Liability of Multinational Corporations” (2002) 20 Berkeley J. Int'l L. 91; Beth Stephens, “The Amorality of Profit: Transnational Corporations and Human Rights” (2002) 20 Berkeley J. Int’l L. 45; John Christopher Anderson, “Respecting Human Rights: Multinational Corporations Strike Out” (2000) 2 U. Pa. J. Lab. \& Employment L. 463; Diane Marie Amann, “Capital Punishment: Corporate Criminal Liability for Gross Violations of Human Rights” (2001) 24 Hastings Int’l \& Comp. L. Rev. 327.

On the importance of building host state capacity as opposed to relying on voluntary corporate social responsibility regimes, see Thomas F. McInerney, "Putting Regulation Before Responsibility: Then Limits of Voluntary Corporate Social Responsibility,”online: Social Science Research Network <http:// papers.ssrn.com/sol3/papers.cfm?abstract_id=658081\#>. 
should also be structured so as to promote rather than detract from democratic decisionmaking. Current practice in this area limits the ability of states to decide the proper balance between protection of foreign investors and the public interest. Host states need to ensure that fairness provisions properly reflect the degree to which they wish to protect investors' expectations and risky investments. Also, if future IIAs require investors to exhaust local remedies before having recourse to international investment arbitration, then it becomes more likely that policies regarding foreign investors will be evaluated in a forum that is part of the democratic decision-making process. Finally, in regard to IIA provisions, states should consider inserting obligations for home states and investors to respect and promote human rights of which the right to democratic governance is an increasingly important part.

In addition to the changes I have suggested for specific types of provisions to be included in IIAs, investment tribunals also have a role to play in supporting democracy in developing countries. My main suggestion has been that tribunals must show appropriate deference to the decisions of governments and to the interpretations of municipal law made by domestic tribunals, which are an important part of the deliberative democratic forum since they shape the rules of deliberation and define the contours of legitimate public reasons. Investment tribunals must still distinguish shams from legitimate democratic decisions. But they must do so by taking greater account of the process used to arrive at a particular government policy. For instance, investment tribunals could consider whether due process of law was observed in the host country's decision to expropriate as part of their decision as to whether the expropriation serves a public purpose or a corrupt private interest. Because deliberative democracy has a respect for difference, the standard of due process should not be a rigid one. Rather, in accordance with the previous discussion of deliberative democracy, the emphasis should be on whether an adequate process had been employed such that the decision to expropriate represented the reasonable and considered decision of the nationals of the host state who would be affected. But furthermore, there should be some consideration of whether, in these deliberations, reasons emerged that justified the deprivation of the foreign investor's investment. This is necessary because of the requirement of reciprocity in democratic deliberation. ${ }^{102}$

Finally, investment tribunals must include experts in the domestic law of the host state, and they should rely on expert opinions about the democratic processes involved in the host state's policy decision and about the interpretation of municipal law. Reasonable deference should be shown to the interpretations of municipal law given by domestic courts, and the reliability of these interpretations can be further enhanced by ensuring that investors exhaust local remedies, thus generating considered local judicial opinions about the rights of the investor under municipal law.

Home states, too, have obligations to ensure that their nationals are responsible and accountable investors. They, like the investors, have a responsibility to promote and protect democratic processes in developing countries by building the capacity of these states to properly assess the impact of foreign investments on the interests of the public. 


\section{Concluding ReMarks: Is Providing Greater FreEdom TO DOMESTIC GOVERNMENTS AT THE EXPENSE OF FOREIGN INVESTORS REALLY DEMOCRACY?}

It seems ironic to advocate for greater freedom for host countries to adopt policies that promote sustainable development if the result is to submit foreign investors to the vagaries of democratic decision-making. If deliberative democracy is committed to ensuring that those who are affected by a decision have a say in the decision-making process, is it not hypocritical to make foreign investors subject to the laws they cannot affect? Is this not the submission of the propertied minority to the whims of the poor majority that Smith feared? In my view, this criticism would be legitimate if it could be argued that the decision to enter into an IIA is a true expression of the will of the nationals of a developing country, and furthermore, if the legitimacy of the norms contained in IIAs could be constantly reevaluated in a democratic deliberative process involving all those affected by them. ${ }^{103}$ However, practice demonstrates that this is not the case. IIAs between developed and developing countries are primarily signed with the purpose of ensuring a stable investment environment for investors from developed countries ${ }^{104}$ and there is little expectation that they will be used by investors from developing countries to challenge developed countries. ${ }^{105}$ Also, while domestic constitutions are difficult to change, the meaning and application of the norms they contain are constantly being revised by successive generations of citizens. ${ }^{106}$ However, IIAs are not hooked into such a process. They are often entered into by developing countries that fear that without an IIA, they will be left out of the "club." And the tribunals that interpret and apply the norms in IIAs are not part of a democratic deliberative process.

A good alternative to the current patchwork of IIAs would be to build the capacity of developing countries to provide an attractive domestic investment environment. But until this alternative is realized, if IIAs are to support democracy, they should contain norms that give more freedom to developing countries to balance the interests of investors and the public. For instance, if IIAs permit state expropriations that have legitimate public purposes, not only does this expand the capacity of the host state to make public policy, it should also provide an incentive for investors to be involved in businesses that also promote public welfare and whose benefits will weigh highly in the democratic forum. As well, it may indirectly provide incentives for foreign investors to be involved in the democratic forum more generally in order to promote changes to the domestic investment regime that applies to all investors domestic and foreign - and to promote sustainable development more generally. As the

103 On the importance of constantly revisiting norms and redefining them through democratic processes, see Seyla Benhabib's concept of “democratic iterations,” which she defines as "linguistic, legal, cultural, and political repetitions-in-transformation, invocations that also are revocations. They not only change established understandings but also transform what passes as the valid or established view of an authoritative precedent”: "Democratic Iterations: The Local, the National, and the Global” in Seyla Benhabib, ed., Another Cosmopolitanism (Oxford: Oxford University Press, 2006) 45 at 48. Jeswald W. Salacuse \& Nicholas P. Sullivan, "Do BITs Really Work?: An Evaluation of Bilateral Investment Treaties and Their Grand Bargain” (2005) 46 Harv. Int’l L.J. 67. J. Anthony VanDuzer, Penelope Simons \& Graham Mayeda, "Modeling International Investment Agreements for Economic Development” in Veniana Qalo, ed., Bilateralism and Development: Emerging Trade Patterns (London: Cameron May, 2008) 359 at 362.

106 On the investment regime as a constitutional regime, see David Schneiderman, Constitutionalizing Economic Globalization: Investment Rules and Democracy's Promise (Cambridge: Cambridge University Press, 2008). 
American experience has demonstrated, the demand for protection of private property increases once the foundations of a sustainable economy have been laid.

\section{THE END OF THE STORY - VIVENDI AND THE PROMOTION OF DEMOCRACY}

I began this article with a question: were the actions of Tucumán authorities that led Vivendi Universal's subsidiary, CAA, to file a claim against Argentina for breach of the Argentina-France BIT an example of democratic action thwarted by the decision of the ICSID Tribunal, or did the government actions expose Argentine democracy in this case to be a sham? It is hard not to interpret the government's actions as a failure to provide due process of law — an important aspect of democratic accountability — to CAA. But I am still left in doubt about the Tribunal's interpretation of events, because it failed to apply an analysis that took the normative content of democracy seriously. As I explained above, an investment tribunal that recognizes its role and the role of IIAs in the promotion of democracy must show reasonable deference to the decisions of state parties that were arrived at through deliberative democratic processes. Also, it should conduct a contextual analysis that permits the tribunal to understand the structures of power, the public interests, and local political norms that informed the government's actions.

The Tribunal in the Vivendi case did not conduct a contextual analysis or understand that it should defer to legitimate government decisions that are necessary to protect and promote the fundamental interests of the residents of Argentina in a rational and reasonable way. For instance, the Tribunal did not explain why Tucumán officials were clearly violating international norms of good governance since the Tribunal did not uncover what private interests state officials were trying to advance. The evidence seems to show that local officials were trying to act on widespread dissatisfaction with the negative impact of the privatization of the water utility on the welfare of residents. If this was the goal, it is understandable that government officials should seek to renegotiate the concession. Thus, the desire to renegotiate is not obviously an example of an improper political motive as the ICSID tribunal maintained. On the contrary, it is an example of a proper motive, and the fault should instead be placed on CAA, which valued the profits it expected from the concession over respect for public welfare and refused a less profitable, renegotiated concession agreement.

The Tribunal also did not use a contextual approach to explain how the acts of the government authorities fit into local conceptions of fairness and public welfare before applying international norms. To the extent that international norms represent a liberal democratic view of democratic legitimacy, the Tribunal thus applied a non-universalizable view of democracy in Vivendi without consideration for local norms, values, and democratic processes. Even with such a nuanced analysis, the outcome might still have been the same. But the failure of the Tribunal to apply an analysis that respects the principles of deliberative democracy brings into question the Tribunal's legitimacy and undermines the promotion of democracy, and ultimately, sustainable development, of which democracy is an important part. 